\title{
CHOCO-JEX A Research Experiment Focused on the Chocó Low-Level Jet over the Far Eastern Pacific and Western Colombia
}

\author{
Johanna Yepes, Germán Poveda, John F. Mejía, Leonardo Moreno, and Carolina Rueda
}

\author{
Scientists and students from Colombia and the United States participated in CHOCO-JEX, \\ the first field campaign to provide upper-air observations over the far eastern Pacific and \\ western Colombia, a region that has one of the rainiest spots on Earth.
}

T he Chocó low-level jet (ChocoJet) is a westerly low-level jet, an extension of the southwesterly cross-equatorial flow that converges over the far eastern Pacific (EPAC) and western Colombia, which exerts a strong modulation over the region's hydroclimate (Poveda and Mesa 1997, 1999, 2000; Mapes et al. 2003a,b; Vernekar et al. 2003; Martínez et al. 2003, 2006; Poveda et al. 2006; Pahnke et al. 2007; Bookhagen and Strecker 2008; Prange et al. 2010; Mollier-Vogel et al. 2013; Gimeno et al. 2016; Grados et al. 2018; Zhao and Keigwin 2018).

AFFILIATIONS: YePES AND POVEDA-Facultad de Minas,

Departamento de Geociencias y Medio Ambiente, Sede Medellín, Universidad Nacional de Colombia, Medellín, Colombia; MejíADepartment of Atmospheric Sciences, Desert Research Institute, Reno, Nevada; Moreno-Dirección General Marítima, Bogotá, Colombia; Rueda—Subdirección de Meteorología, Fuerza Aérea Colombiana, Bogotá, Colombia CORRESPONDING AUTHOR: Johanna Yepes, ljyepes@unal.edu.co

The abstract for this article can be found in this issue, following the table of contents.

DOI:10.II75/BAMS-D-18-0045.I

In final form 9 December 2019

(-2019 American Meteorological Society

For information regarding reuse of this content and general copyright

information, consult the AMS Copyright Policy.
The orographic interaction of ChocoJet with the downstream Andes has been linked to the existence of arguably the rainiest place on Earth, experiencing mean annual rainfall rates on the order of 13,000 $\mathrm{mm}$, as documented by numerous studies (Murphy 1939; Schmidt 1952; Trojer 1958; Arnett and Steadman 1970; Snow 1976, p. 371; Meisner and Arkin 1987; Eslava 1993, 1994; Janowiak et al. 1994; Poveda and Mesa 2000; Mapes et al. 2003a,b; Warner et al. 2003; Zuluaga and Poveda 2004; González et al. 2006; Pahnke et al. 2007; Sakamoto et al. 2011; Álvarez-Villa et al. 2011; Durán-Quesada et al. 2012; Sierra et al. 2015; Jaramillo et al. 2017; King et al. 2017). The ChocoJet feeds the highly biodiverse tropical rain forest that spreads over the Chocó-Darién region along the Colombian Pacific. Consistently, the region is home to communities exposed to extreme precipitation and recurrent flood events (Velásquez and Poveda 2019, manuscript submitted to Rev. Dyn.; Jaramillo et al. 2017) and is one of the most critical hot spots around the world in terms of biodiversity loss (Myers et al. 2000). Scientific understanding of the role of the ChocoJet in the region's hydroclimate and ecosystems has relied on remote sensing and reanalysis tools. Therefore, in situ observations that characterize the atmospheric circulation over these regions and help constrain reanalysis and operational models 
The existence of the Chocó low-level jet is related to the southwesterly branch of the southerly cross equatorial flow over the far eastern Pacific (Chocojet; Poveda and Mesa 1999, 2000). It is driven by the seasonal variability in the gradient of sea surface temperatures (SSTs) between the Niño-I+2 region and the Colombian Pacific, which is stronger during September-November and weaker during February-March (Poveda and Mesa 1999). Reanalysis data at $925 \mathrm{hPa}$ show weak southwesterlies (2-3 $\mathrm{m} \mathrm{s}^{-1}$ ) during March-April and a stronger and deeper transequatorial southwesterly flow (6-8 $\mathrm{m} \mathrm{s}^{-1}$ ) during SeptemberNovember (Fig. SBI). Figure SB2 shows the vertical distribution of the zonal wind at $80^{\circ} \mathrm{W}$, with data from the ERA-I reanalysis. It exhibits a shallow jet during September-November and a more intense and deeper jet in SeptemberNovember around $5^{\circ} \mathrm{N}$ (Fig. SB2). The annual cycle of precipitation over the western and Andean region of
Colombia is modulated by the migration of the intertropical convergence zone (ITCZ). The location of the ITCZ causes two wet seasons (April-May and September-November) and two dry seasons (December-February and June-August) over central and western Colombia (Fig. SBI). The second wet season (September-November) has been linked to the significant moisture transport from the Pacific Ocean through an enhanced Chocojet (Poveda 2004).

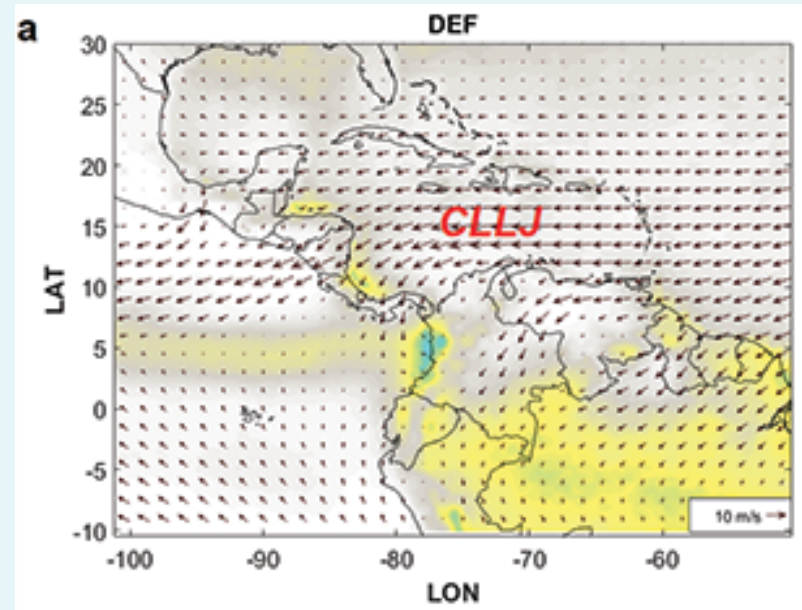

C

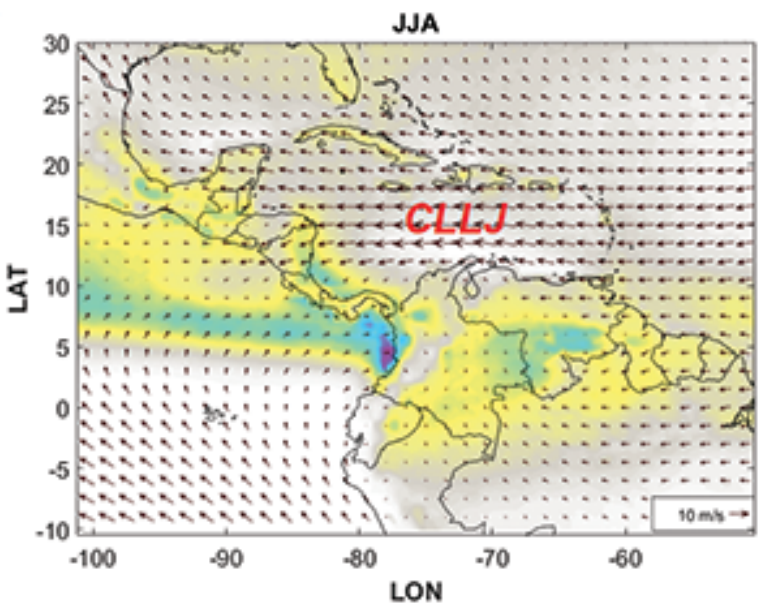

b

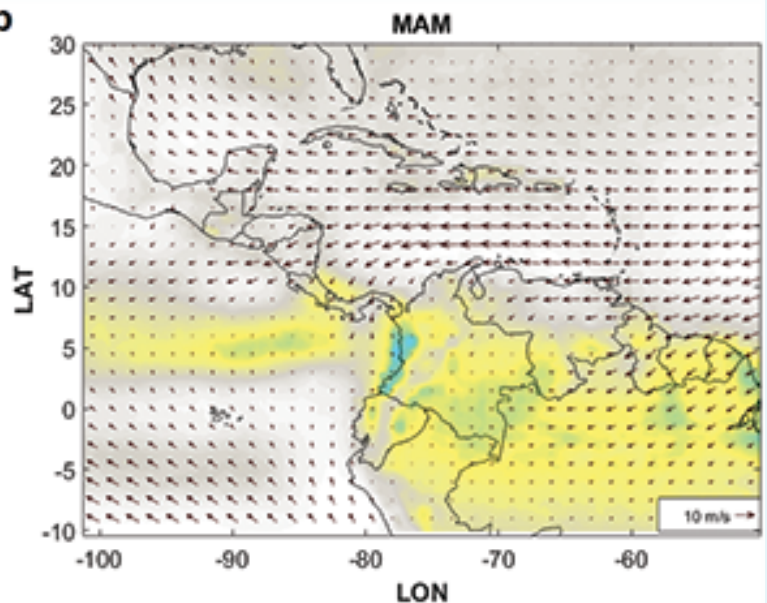

d

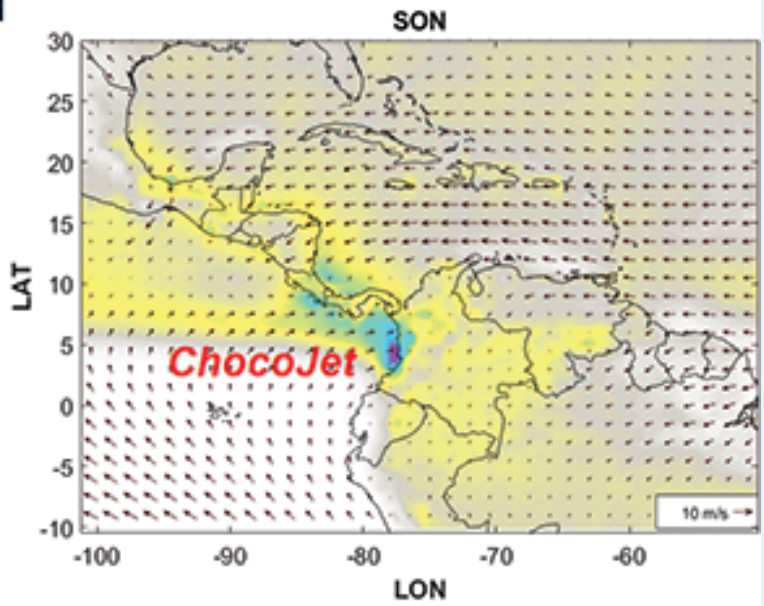

30

FIG. SBI. The $925-\mathrm{hPa}$ long-term mean (1980-2016) wind vectors and precipitation (shaded contours; $\mathrm{mm} \mathrm{day}^{-1}$ ) based on ERA-I averaged during (a) Dec-Feb, (b) Mar-May, (c) Jun-Aug, and (d) Sep-Nov. 
The Caribbean low-level jet (CLLJ) exhibits a pronounced annual cycle with peak winds at $925 \mathrm{hPa}$ during July $\left(14 \mathrm{~m} \mathrm{~s}^{-1}\right)$ and during January-February $\left(10 \mathrm{~m} \mathrm{~s}^{-1}\right)$ (Amador 2008). The enhanced jet in July has been related to the seasonal variability of the North Atlantic subtropical high (RomeroCenteno et al. 2007). The jet weakens from September to November associated with relatively weak trade winds, reduced vertical wind shear, increased hurricane activity, and peak precipitation over Central America (Amador 2008). In late November when trade winds increase again, CLLJ strengthens and it reaches a maximum in February linked to increased heating over northern South America (Cook and Vizy 2010). The vertical distribution of CLLJ shows an extension of the jet upward to $700 \mathrm{hPa}$ in boreal summer, while the jet reaches up to 850 during boreal winter. The displacement of the CLLJ in the east Pacific by the Chocojet in the boreal autumn is associated with strong precipitation over the study region (Poveda and Mesa 2000). This displacement is modulated by El Niño-La Niña, with the latter resulting in an enhanced Chocojet and even stronger rainfall, as, for example, during the La Niña of 20I0-II (Arias et al. 20I5).
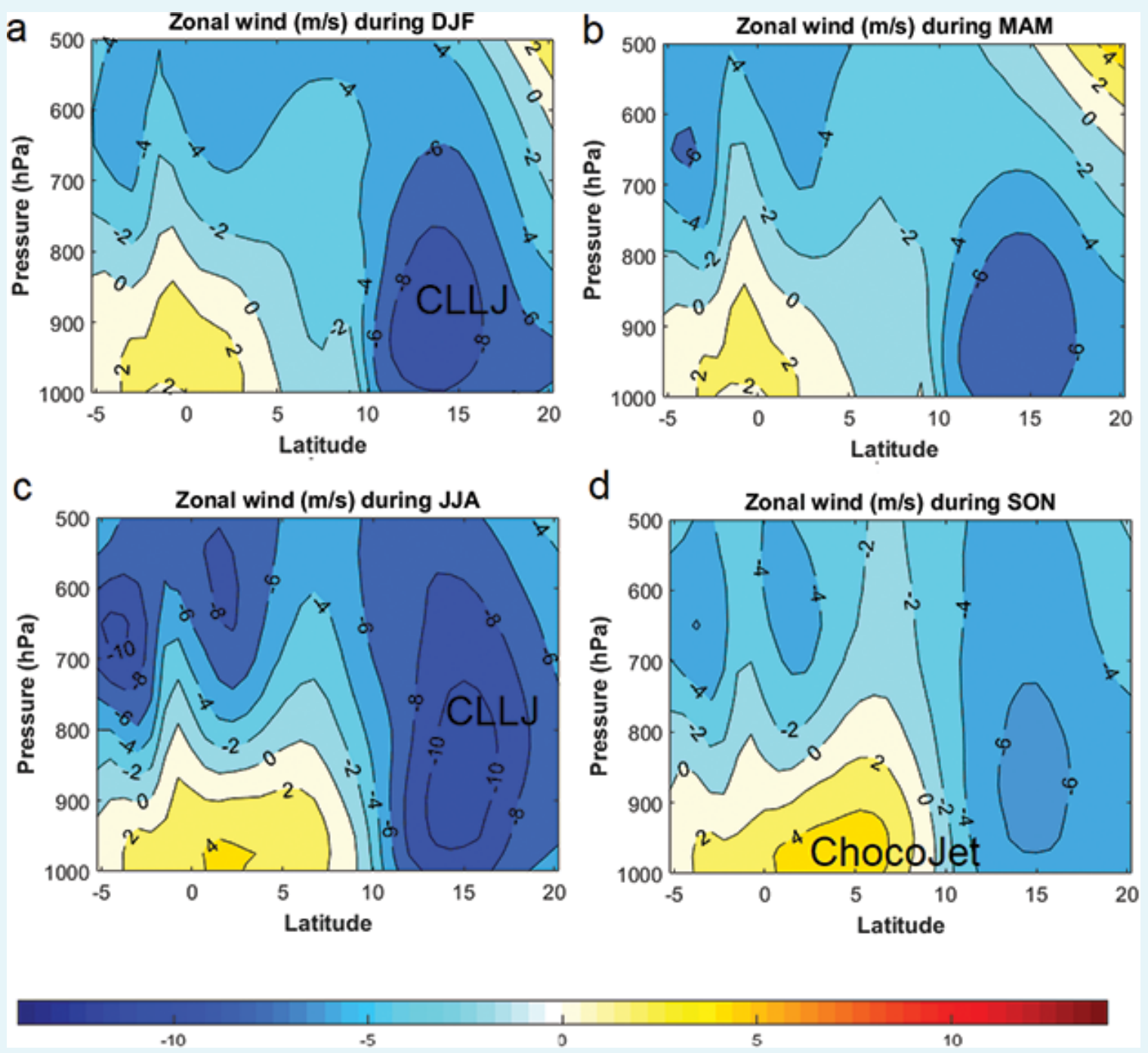

Fig. SB2. Vertical distribution of mean (1980-2016) zonal winds ( $\left.\mathrm{m} \mathrm{s}^{-1}\right)$ based on ERA-I at $80^{\circ} \mathrm{W}$ during (a) Dec-Feb, (b) Mar-May, (c) Jun-Aug, and (d) Sep-Nov. 
are of critical importance in accurately improving such understanding (see the "Chocó and Caribbean low-level jets climatology" sidebar).

During the boreal autumn, the ChocoJet is related to the wet season over the western and central regions of Colombia (Poveda and Mesa 2000; Rueda and Poveda 2006). During this period, reanalysis shows a 4-6 $\mathrm{m} \mathrm{s}^{-1}$ jet with its core at the 925-hPa level. ChocoJet's diurnal, synoptic, and seasonal variabilities are influenced by regional circulation features, including the Caribbean low-level jet (CLLJ; Poveda and Mesa 1999; Amador 2008; Poveda et al. 2014; Arias et al. 2015), the intertropical convergence zone (ITCZ;

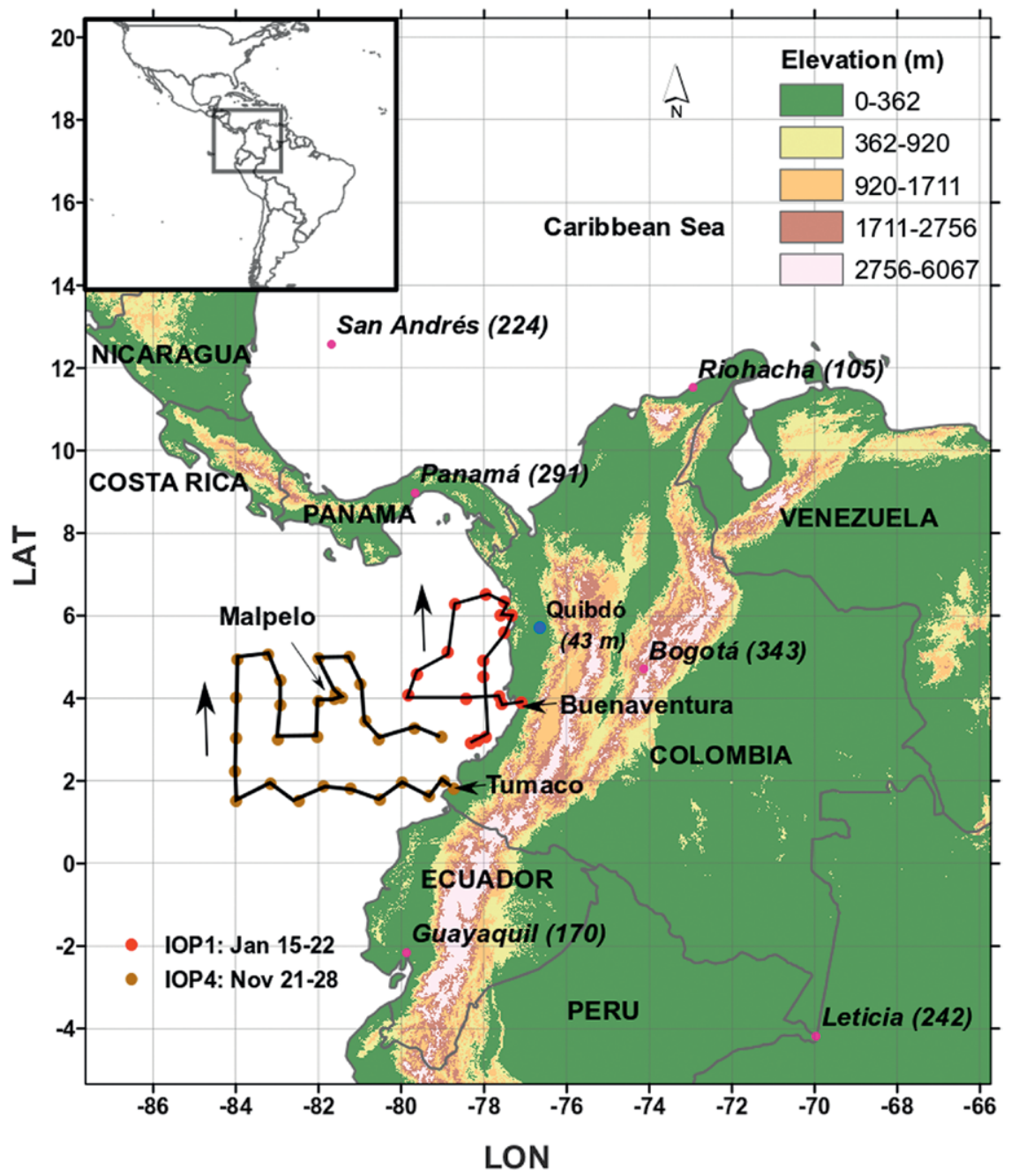

FIG. I. CHOCO-JEX region of interest and IOP locations. Black lines show ARC Gorgona vessel tracks during IOPI (red dots) and IOP4 (brown) with each dot indicating an individual sounding launch position. Inland soundings (IOP2 and IOP3; see text for description) were launched from Quibdó (43 m ASL) (blue point). Locations and names of the regional operational soundings (in purple) are also shown (Panamá, Panama; Guayaquil, Ecuador; and Leticia, Bogotá, and Riohacha, Colombia) including the average number of soundings per year released during the period $2012-16$. Malpelo island $\left(4.0061^{\circ} \mathrm{N}\right.$, $81.5936^{\circ} \mathrm{W}$ ) is indicated as a strategic location for future oceanic campaigns.
Schneider et al. 2014), and the predominant easterly flow over the Andes (López and Howell 1967; Poveda et al. 2014). The ChocoJet has been linked to the frequent formation of nighttime and early morning mesoscale convective systems (MCSs; Mejía and Poveda 2005; Zuluaga and Houze 2015; Jaramillo et al. 2017) over western Colombia and the Panama Bight, contributing approximately $57 \%$ of the total rainfall in the region (Jaramillo et al. 2017). At seasonal scales, the CLLJ interacts with the ChocoJet and modulates the meridional location of the ITCZ (Arias et al. 2015). At interannual scales, El Niño years tend to be associated with a weaker ChocoJet, thus contributing to the explanation of prolonged drier periods over the Colombian Andes, with the reverse occurring during La Niña (Poveda and Mesa 1997, 1999, 2000; Poveda et al. 2001, 2006), a finding that appears to be linked to a wetter precipitation pattern observed during El Niño over northern Peru and Ecuador (Douglas et al. 2009). The interannual variability of CLLJ is seasonally modulated. During boreal winter, the jet weakens during El Niño and strengthens during La Niña. During boreal summer, the opposite relationships have been found (Amador et al. 2006; Wang 2007).

Despite the intricate atmospheric circulation patterns over the eastern equatorial Pacific and the seemingly significant influence on the meteorology, hydrology, and ecosystems of northwestern South America, no permanent or even experimental in situ upper-air measurements are available to characterize the atmospheric profile and the ChocoJet flow vertical structure and variability. Figure 1 shows the location of regional upper-air sounding systems, also indicating how spatially sparse and 
infrequent operational real-time observations were during the last five years. Despite the existence of Panamá and Guayaquil observations on the Pacific basin, different aspects (e.g., budget constraints, landmass distribution, logistical difficulties) have prevented the development of a potentially better and denser upperair soundings network. Thus, the ChocoJet Experiment (CHOCO-JEX) was designed to start addressing the gap in observations through a set of field campaigns focused on upper-air soundings launched offshore from a research vessel and inland from the Universidad Tecnológica del Chocó at Quibdó (Fig. 1). Quibdó is the capital city of the Chocó province in Colombia and is located between the coastline and the westernmost Andes. CHOCO-JEX observations are crucial for a suite of diverse purposes including characterizing the atmospheric profile, evaluating reanalysis products, and assessing numerical simulations of the ChocoJet structure. Also, these observations will contribute to elucidating the role of gravity waves (Mapes et al. 2003b) in the diurnal cycle of precipitation over the region. Overall, CHOCO-JEX observations will contribute to improving the region's hydroclimate predictive capabilities.

CHOCO-JEX, mainly funded by the Colombia Administrative Department of Science, Technology and Innovation (COLCIENCIAS), was made possible through a collaborative effort between Universidad Nacional de Colombia at Medellín, the General Maritime Directorate (DIMAR) of the Ministry of National Defense of Colombia, the Colombian Air Force (FAC), and the Desert Research Institute (DRI) Reno, Nevada. Here, we present a synthesis of the field campaigns conducted in 2016 and highlight the potential scientific understanding and the hypotheses driving the overall research project. Additionally, we identify some of the practical limitations and leverage opportunities related to the field campaigns. We present some preliminary results, discuss the capacity for future atmospheric field campaigns, and describe some of the education and outreach opportunities enabled through this project.

From sociopolitical conflicts to scientific wondering. For 52 years, Colombia endured an internal armed conflict between the national government and leftist guerrillas, with added involvement of extreme right-wing paramilitary groups. This conflict left 8 million victims, including 6.7 million displaced persons; more than 220,000 casualties; 11,000 victims of antipersonal mines; 45,000 forced disappearances; 30,000 kidnappings; and more than 2,000 massacres (GMH 2013). Between 2012 and 2016 the Colombian government led by President Juan Manuel Santos and FARC (the largest and oldest armed rebel group) held talks in Havana, Cuba, and despite many difficulties, a peace agreement supporting a Definitive and Bilateral Cease of Fire and Hostilities was signed on 24 November 2016. The cost of the protracted warfare was enormous for Colombia, in the toll of victims and human suffering as well as in the diversion and depletion of national economic resources. Besides the internal conflict, inadequate funding for scientific research in Colombia has been caused by the historical disregard of governments of the importance of science, technology, innovation, and the humanities to improve the socioeconomic conditions and enhance the cultural life of the country (Poveda 2001), but also by ignoring the scientific community in the design of relevant scientific agendas (Poveda 2004). In contrast, CHOCO-JEX brings together several educational, research, and public/defense institutions around relevant scientific challenges with huge potential benefits for all the institutions involved and the country in general. This collaborative effort constitutes an example of the benefits of cooperative research between the largest public university of Colombia and the military (Colombian Air Force and DIMAR) for the postaccord peace era. See the "Capacity building" sidebar.

CHOCO-JEX. CHOCO-JEX is a multi-institutional collaborative effort, aimed at observing key aspects of the low- to upper-level flow, thermodynamic structure, and temporal variability over the far eastern Pacific region, including the ChocoJet and inland over northwest Colombia. The experiment was conducted in 2016 and consisted of four intensive observational periods (IOPs), each lasting a week; two of which were over the Pacific Ocean and two inland. Because of our interest in understanding diurnal and dayto-day variability, each IOP consisted of 6-hourly upper-air rawinsondes-measuring temperature, horizontal wind components, pressure, and relative 
humidity-distributed as shown in Table 1 (see Fig. 1). A website currently under construction (https://sites .google.com/unal.edu.co/chocojex/home) will provide diverse data products and resources derived from CHOCO-JEX.

Experimental design: From the ideal to the real. CHOCOJEX was designed to take advantage of the regular oceanographic survey carried out as part of the Estudio Regional del Fenómeno El Niño project (ERFEN), a regional coordinated effort among Chile, Peru, Ecuador, and Colombia aimed at monitoring physical and biological upper-ocean variables near the continental shelf (CPPS 2017). The Colombian ERFEN component is coordinated and implemented by DIMAR. Typically, each country commits research vessels with at least one campaign during September-October. Seasonally, the ChocoJet is most intense during September-November (Poveda and Mesa 1999; Poveda et al. 2014). Hence, our original plan was to carry out simultaneous maritime and land observations that coincided with the 2015 and 2016 ERFEN campaigns. Our interest in conducting simultaneous measurements during the 2015 Colombian ERFEN campaign, however, had to be adjusted because of unscheduled research vessel maintenance, shifting departure from early October 2015 to mid-January 2016.
Another striking challenge in this experiment was the unpredictable exchange rates, as the funding was provided in Colombian pesos (COPs) and the costs for rawinsondes, receiver systems, and balloons were quoted and purchased in U.S. dollars. There was an unexpected devaluation of the COP (nearly $40 \%$ from the time the proposal was submitted in 2014 to purchasing and acquisition in 2015) relative to the U.S. dollar, forcing us to scale down the original field campaigns. Hence, from the original 168 rawinsondes and balloons (10 days per IOP), only 120 were purchased (7 days per IOP). Despite the outlined difficulties, four IOPs were developed successfully. Figure 2 shows some of the activities carried out during CHOCO-JEX.

Instrumentation. The instrumentation acquired for the field campaigns included the following: a Vaisala DigiCORA MW41 sounding system, an RI41 Ground Check Device, Vaisala RS41-SG radiosondes, and TA200 meteorological balloons. The sounding system allowed us to measure vertical profiles of atmospheric pressure, temperature, relative humidity, magnitude, and wind direction.

The Armada de la República de Colombia (ARC) Gorgona vessel from DIMAR was the launching

CAPACITY BUILDING

Uistorically, the far eastern Pacific Hhas lacked upper-air observations. Previous attempts to perform upper-air soundings in the region failed because of difficulties in accessing the area as a result of complex terrain and weather, safety and security issues, and a lack of interinstitutional cooperation to overcome these challenges. The collaborative CHOCO-JEX program was made possible by funding from COLCIENCIAS and the in-kind support of the participating institutions during the field campaigns over maritime areas as well as remote and difficult-to-access lands. The Universidad Nacional de Colombia at Medellín, which makes up part of the largest public university in Colombia, was the leading institution in charge of the project's scientific, financial, and logistical components. During the field campaigns, FAC's in-kind support consisted of flying personnel and equipment from Medellín to the facilities of the Center of Oceanographic and Hydrographic Research of the Pacific (DIMAR's Pacific research branch), and between Medellín and Quibdó. DIMAR facilitated this coordination and provided resources for one of the graduate students to be part of the Regional Study of the El Niño Southern Oscillation [Comisión Multisectorial Encargada del Estudio Nacional del Fenómeno El Niño (ERFEN)] campaigns. DRI collaborated in all stages of the project's development and execution, provided expertise in atmospheric sciences and field campaigns, and contributed with in-kind support consisting of high-performance computing and analytical resources to complete the modeling component of this project (not described here). This networking among Colombian public institutions and an international research institute was one of CHOCO-JEX biggest goals and achievements.

Furthermore, the interinstitutional network created by CHOCO-JEX extended to additional activities such as the exchange of knowledge with other research groups and additional field campaigns. For example, the infrastructure and connections acquired during $\mathrm{CHOCO}$ JEX have enabled us to participate in SeaFlower-2016, a Colombian scientific expedition in Cayo Serrana, a remote Caribbean islet that makes up part of the Colombian archipelago of San Andrés and Providencia [the SeaFlower Biosphere Reserve was recognized by the United Nations Educational, Scientific and Cultural Organization (UNESCO) in 2000]. SeaFlower-2016 was a transdisciplinary field campaign designed to study this remote region, which is affected by the CLLJ. We collected atmospheric profiles during this field campaign to study the airflow-sea interaction in the region and to help better understand the synoptic conditions during the observation period. 
platform during the oceanic campaigns. For more than 50 years, the ARC Gorgona has accomplished different operational and research tasks related to hydrography, maritime signposting, and support to the Colombian national navy. During the ERFEN campaigns, ARC Gorgona aims to measure diverse vertical and horizontal column water characteristics.

\section{FIELD CAMPAIGN ACHIEVEMENTS AND} PRELIMINARY RESULTS. The original CHOCOJEX plan was to gather observations during the enhanced ChocoJet season (September-November) to increase the chance of observing environmental conditions that resembled enhanced low-level southwesterly flow. All IOPs were deployed throughout rapidly changing ENSO conditions, as classified by the oceanic Niño index [ONI; National Oceanic and Atmospheric Administration/Climate Prediction Center (NOAA/CPC; https://origin.cpc.ncep .noaa.gov/products/analysis_monitoring/ensostuff /ONI_v5.php)]. However, each of the four campaigns was heavily constrained by diverse unscheduled logistical hurdles (some of which are highlighted above). The synoptic intraseasonal, seasonal, and interannual identifiable environmental conditions during each campaign included the following.

1) IOP1 (15-22 January 2016): This IOP was carried out during one of the strongest El Niño events ever recorded (L'Heureux et al. 2017). According to the Instituto de Hidrología, Meteorología y Estudios Ambientales (IDEAM; Institute of Hydrology, Meteorology and Environmental Studies), January 2016 was characterized by anomalously dry conditions over most of Colombia (IDEAM, 2016a). Climatologic studies have shown that during El Niño conditions, most of Colombia is typically associated with relatively dry conditions (Poveda et al. 2001, 2011; Bedoya-Soto et al. 2018), while the coasts of northern Peru and southwest Ecuador experience wetter conditions (Sulca et al. 2018). Figure 3a shows wind anomalies during January 2016, highlighting several regional patterns including a stronger than normal Panama jet (Xie et al. 2005); the Corriente de los Andes Orientales (CAO or eastern Andes jet, also known as the Llanos jet; Montoya et al. 2001; Torrealba and Amador 2010), which constitutes the northernmost leg of the
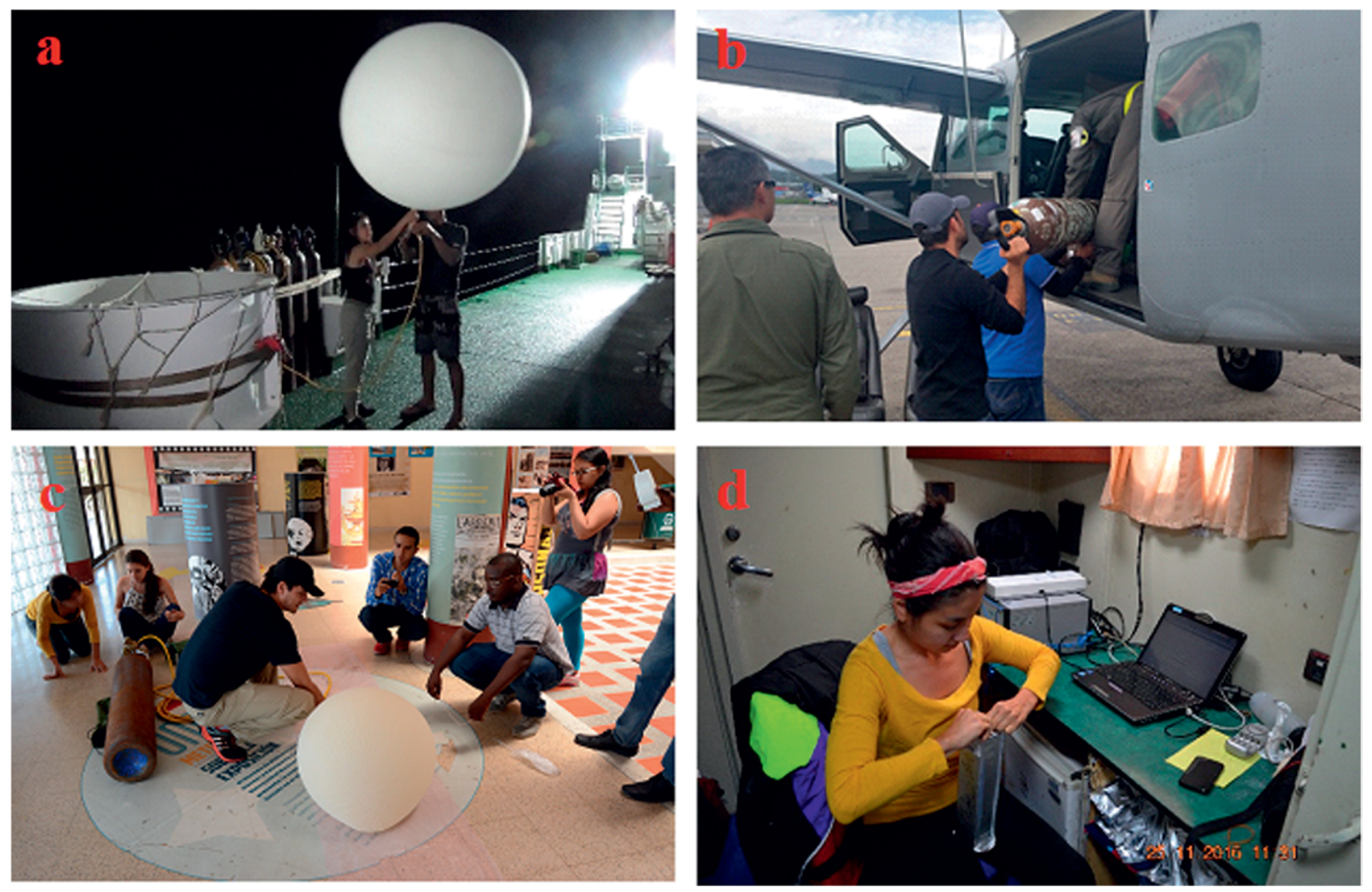

FIG. 2. Selected images of CHOCO-JEX activities: (a) launch of a radiosonde from ARC Gorgona in Jan, (b) shipment of personnel and helium gas cylinders by the FAC in Oct, (c) inflation of a balloon inland in Quibdó at Universidad Tecnológica del Chocó in Jun, and (d) sounding setup on board the ARC Gorgona in Nov. 
South American low-level jet (SALL); Vera et al. 2006); and weaker than normal CLLJ (Amador et al. 2006; Wang 2007), Papagayo, and Tehuantepec jet patterns (Xie et al. 2005). These anomalous flow conditions over the eastern Pacific resembled those of the 1997/98 El Niño event (Douglas et al. 2009). In particular, IOP1 showed a relatively weak ChocoJet dominated by a stronger Panama jet.

2) IOP2 (25 June-1 July 2016): IDEAM reported that precipitation over Colombia was below normal for this time of the year, with near-neutral ENSO conditions over the tropical Pacific (IDEAM 2016b). Additionally, IDEAM indicated that the

a

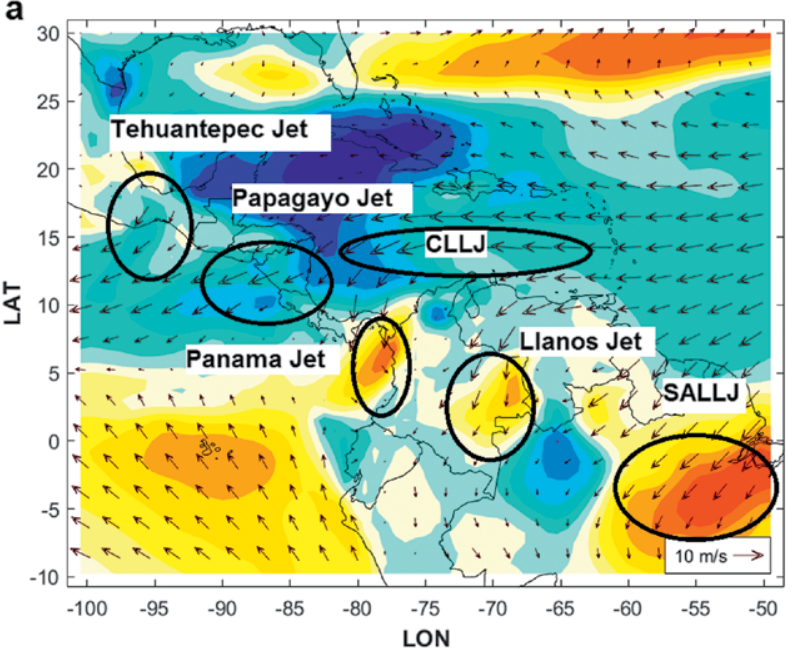

b

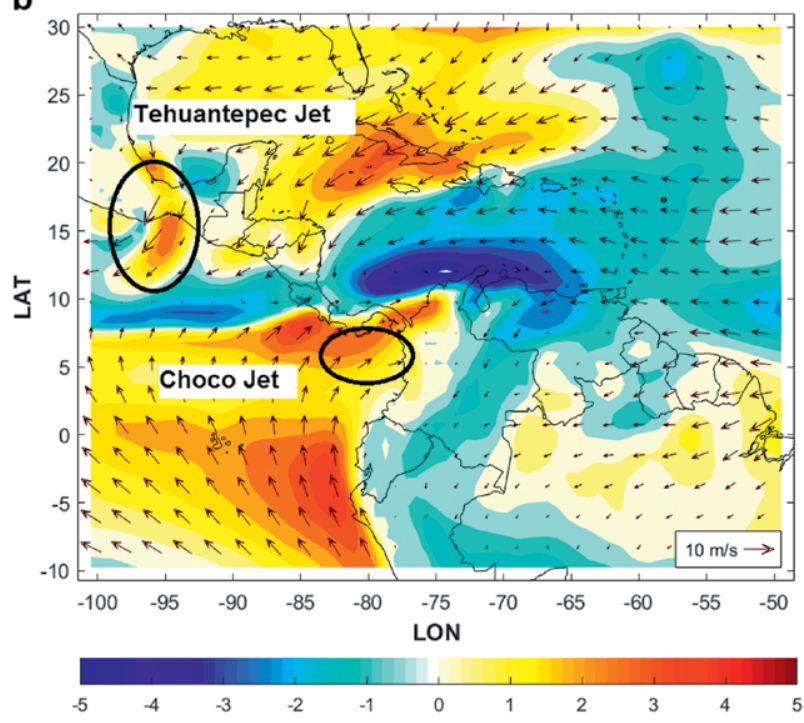

Fig. 3. The 925-hPa average winds (vectors) and wind speed anomalies (filled contours; relative to 19802016) during (a) Jan and (b) Nov 2016. Circles represent the regional low-level jets identified during IOPI and IOP4: CLLJ, Papagayo jet, Tehuantepec jet, Panama jet, Llanos jet, South American low-level jet (SALLJ), and Chocojet.
ITCZ was displaced to the north over Central America and the northern Colombian Pacific coast, enabling low-level southwesterlies to reach the far eastern Pacific region (Poveda and Mesa 1999). During this IOP, the CLLJ was anomalously strong.

3) IOP3 (15-21 October 2016): Weak La Niña conditions were predominant during October 2016. IDEAM reported normal precipitation over western Colombia, an ITCZ trough axis that was located over the EPAC $\left(6^{\circ}-15^{\circ} \mathrm{N}\right)$, and scattered precipitation events over the northern and central Colombian Pacific coast (IDEAM 2016c). At a regional scale, no tropical storm activity occurred near or during this IOP.

4) IOP4 (21-28 November 2016): IDEAM reported that the Pacific Colombian coast showed nearnormal precipitation conditions, likely influenced by the La Niña phase over the tropical Pacific (IDEAM 2016d). Regional circulation features during this month (Fig. 3b) resembled those shown by Arias et al. (2015) for the 2010-12 La Niña event dominated by a relatively stronger than normal ChocoJet and weaker than normal CLLJ. Preliminary analysis suggests that both of these regional features were also observed during IOP4 (Fig. 3). Tropical Storm Otto was located over the western Caribbean Sea and transitioned into a hurricane system before moving away over Central America and the Pacific basin (20-26 November). Thus, we hypothesized that the first half of IOP4 was influenced by Otto's circulation.

Figures $4 \mathrm{a}, \mathrm{c}$ and $5 \mathrm{a}, \mathrm{c}$ show the zonal moisture flux during the four IOPs. A shallow westerly component around $50 \mathrm{~g} \mathrm{~kg}^{-1} \mathrm{~m} \mathrm{~s}^{-1}$ at low levels was observed during IOP1, showing a diurnal signal on 18-19 January associated with the proximity to land (see Fig. 1). An easterly component $\left(50 \mathrm{~g} \mathrm{~kg}^{-1} \mathrm{~m} \mathrm{~s}^{-1}\right)$ was prevalent at midlevels and in some cases at low levels. At subdaily time scales, IOP2 and IOP3 showed relatively large diurnal variability, likely related to land-sea and valley-mountain breezes, with a stronger afternoon westerly component around $50-100 \mathrm{~g} \mathrm{~kg}^{-1} \mathrm{~m} \mathrm{~s}^{-1}$ and a weaker early morning easterly component around $20 \mathrm{~g} \mathrm{~kg}^{-1} \mathrm{~m} \mathrm{~s}^{-1}$. This diurnal cycle was stronger during IOP3 than during IOP2. At midlevels, the observed easterly moisture flux was up to $100 \mathrm{~g} \mathrm{~kg}^{-1} \mathrm{~m} \mathrm{~s}^{-1}$ during IOP2, whereas IOP3 showed values around $20 \mathrm{~g} \mathrm{~kg}^{-1} \mathrm{~m} \mathrm{~s}^{-1}$. In contrast, westerly moisture flux $\left(50 \mathrm{~g} \mathrm{~kg}^{-1} \mathrm{~m} \mathrm{~s}^{-1}\right)$ at low levels and easterly moisture flux $\left(15 \mathrm{~g} \mathrm{~kg}^{-1} \mathrm{~m} \mathrm{~s}^{-1}\right)$ at midlevels prevailed along with high variability in the wind profile during IOP4. 

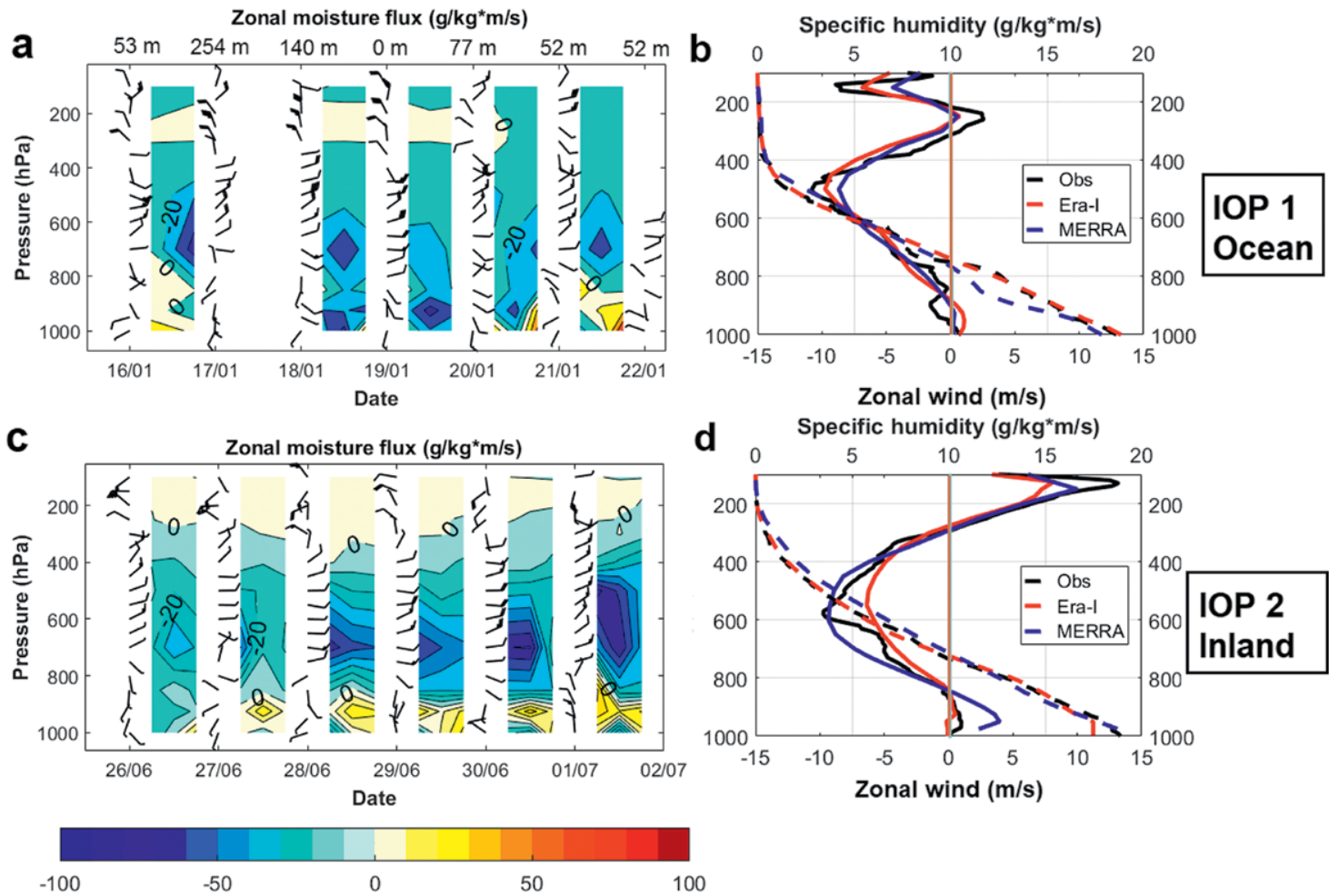

FIG. 4. (a) Time-longitude diagram of zonal moisture flux from observations $\left(\mathrm{g} \mathrm{kg}^{-1} \mathrm{~m} \mathrm{~s}^{-1}\right)$ and (b) averaged zonal wind profiles $\left(\mathrm{m} \mathrm{s}^{-1}\right)$ and specific humidity profiles from observations (black line), ERA-I (red line), and MERRA (blue line) during IOPI. (c),(d) As in (a) and (b), but during IOP2. Thick date marks indicate 1900 LST (0000 UTC). The top $x$ axis during the oceanic campaign indicates the distance $(\mathrm{m})$ of the particular sounding relative to the coast.
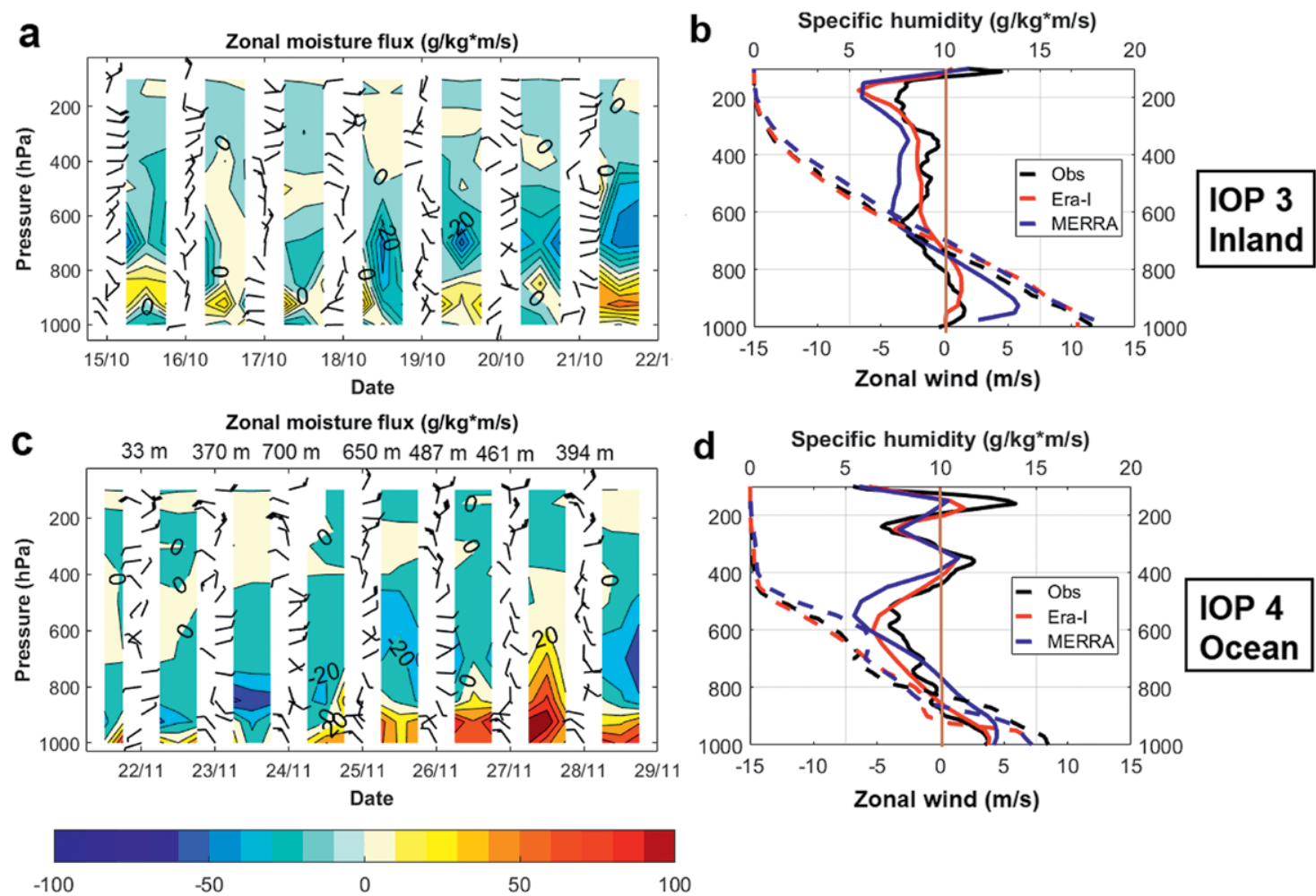

Fig. 5. As in Fig. 4, but for IOPs 3 and 4. 
Since the IOP4 shows a strong ChocoJet (Figs. 4 and 5), we examined composites of circulation along with vertical integrated water vapor from the Modern-Era Retrospective Analysis for Research and Applications (MERRA) at $850 \mathrm{hPa}$ and IR satellite images (Fig. 6). This IOP shows two different pronounced synoptic conditions: i) predominant meridional and drier flow likely influenced by Otto's depression between 21 and 24 November and ii) westerly and wetter flow from 25 to 28 November. A particular feature during IOP4 is that convection activity and precipitation over western Colombia was suppressed until 24 November. Later during the second synoptic event, a wet spell of scattered convection and sustained MCSs developed on 25 and 27 November over northern Colombian Pacific. Overall, MERRA shows a deeper low-level southwesterly flow than seen in observations during the first event. At any rate, both datasets coincide with strong southwesterlies during the second event.

Observations show that during the first synoptic event discussed above a relatively weaker westerly (no significant differences in meridional flow were observed) and low-level moisture flux of $50 \mathrm{~g} \mathrm{~kg}^{-1} \mathrm{~m} \mathrm{~s}^{-1}$ were present, in combination with an easterly moisture flow at midlevels; and during the second synoptic event a deeper and more intense westerly moisture flux of $80-100 \mathrm{~g} \mathrm{~kg}^{-1} \mathrm{~m} \mathrm{~s}^{-1}$. We hypothesize that after Otto moved away from the region, a more zonal low-level flow was established, with enhanced southwesterly moisture flow favoring moisture flux convergence and orographic forcing. Coinciding with this period of enhanced precipitation, however, were observed larger convection indices, such as convective available potential energy (CAPE) and helicity (not shown).
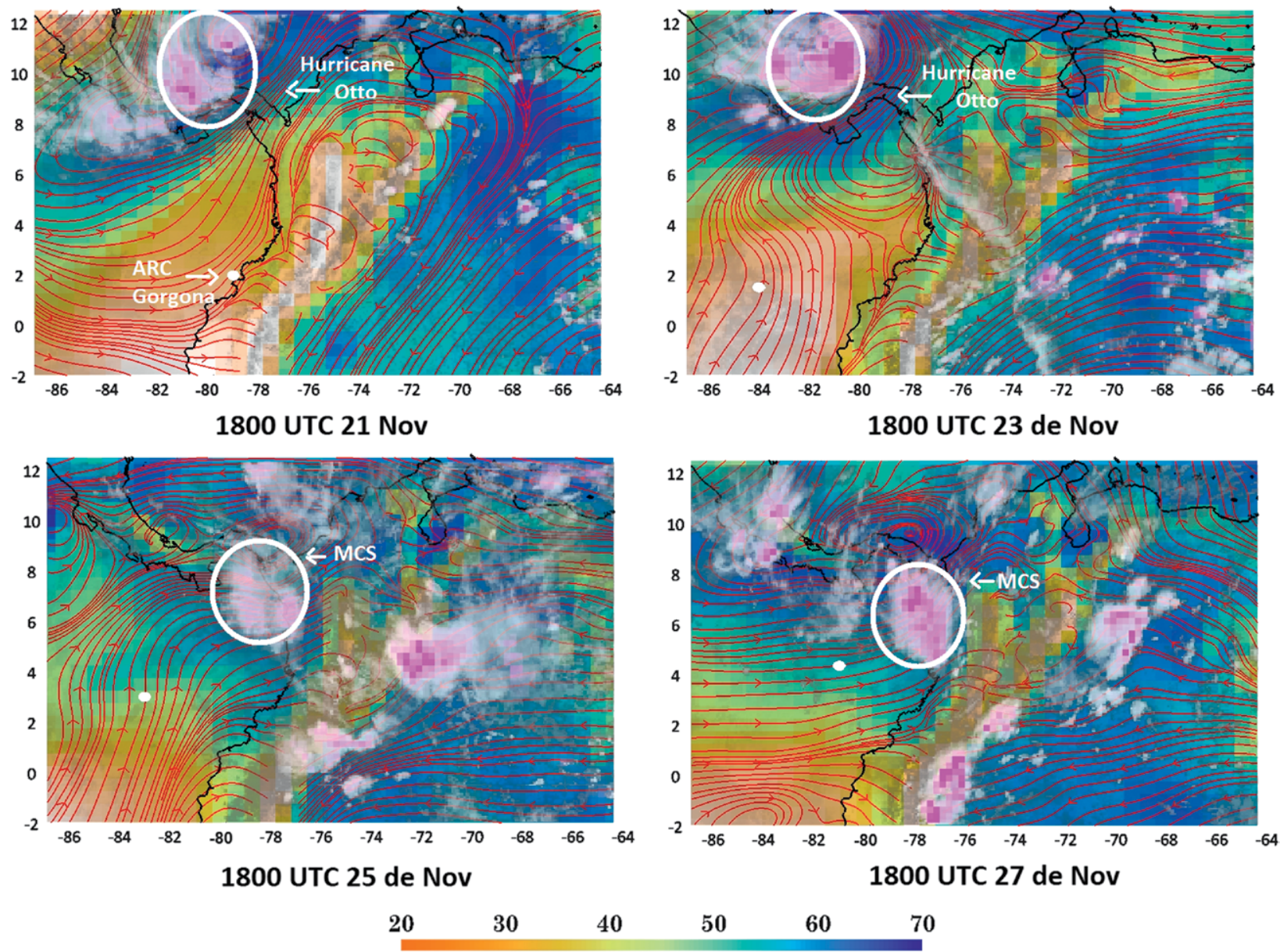

FIG. 6. Vertically integrated water vapor ( $\mathrm{mm}$; filled contours) and streamlines at $850 \mathrm{hPa}$ from MERRA2, and IR images from GridSat-Geostationary Operational Environmental Satellite (GOES) (light green shading indicative of rainfall from Tropical Rainfall Measuring Mission algorithm TRMM3B42) during IOP4. Hurricane Otto is observed on 21 and $23 \mathrm{Nov}$ over $10^{\circ} \mathrm{N}, 81^{\circ} \mathrm{W}$. Long-lasting MCSs developed around $7^{\circ} \mathrm{N}, 78^{\circ} \mathrm{W}$ on 25 and 27 Nov. ARC Gorgona's position over the EPAC is indicated by the white dots. 
Figures $4 \mathrm{~b}, \mathrm{~d}$ and $5 \mathrm{~b}, \mathrm{~d}$ also show the vertical distribution of the zonal wind component and specific humidity averaged during each IOP, along with the same vertical profiles using European Centre for Medium-Range Weather Forecasts (ECMWF) interim reanalysis (ERA-I) and MERRA products. IOP1 and IOP2 showed weak westerly flow at low levels $\left(<2 \mathrm{~m} \mathrm{~s}^{-1}\right)$ that was deeper (up to $900 \mathrm{hPa}$ ) during IOP2. At midlevels, easterlies were predominant between 800 and $300 \mathrm{hPa}$ with maximum values around $10 \mathrm{~m} \mathrm{~s}^{-1}$ at $500 \mathrm{hPa}$. In general, IOP3 and IOP4 showed low-level southwesterlies that resembled ChocoJet conditions (Poveda and Mesa 1999). Both IOP3 and IOP4 showed a weak, low-level, zonal wind (2-4 $\left.\mathrm{m} \mathrm{s}^{-1}\right)$ extending from the surface up to $850 \mathrm{hPa}$ with maximum results around $925-950 \mathrm{hPa}$. Midlevel easterly flow was observed above $850 \mathrm{hPa}$ during both campaigns, with values below $5 \mathrm{~m} \mathrm{~s}^{-1}$. Specific humidity profiles were similar during all IOPs with exception of IOP4, which showed a drier profile from low to midlevels and values below $10 \mathrm{~g} \mathrm{~kg}^{-1}$ at low levels in connection with Otto (Fig. 6). Observations showed high day-to-day variability with stronger westerlies at low levels during 17-18 October and 26-27 November, reaching values of 6-7 $\mathrm{m} \mathrm{s}^{-1}$ (not shown). During IOP4, low-level westerlies and the specific humidity increased after Otto moved away from the region on 26 November.

Overall, ERA-Interim and MERRA results show the vertical variability of the zonal wind and specific humidity during each IOP; however, some bias can be distinguished, such as the more pronounced and deeper ChocoJet, as represented by MERRA during inland campaigns. Oceanic campaigns exhibited better agreement than those over land, likely associated with the misrepresentation of dynamic and thermodynamic processes over complex terrain. However, during IOP4, both reanalyses exhibit a ChocoJet-like feature, with peak zonal winds between 4 and $5 \mathrm{~m} \mathrm{~s}^{-1}$ at 950-975 hPa; MERRA resolves a deeper and about $2 \mathrm{~m} \mathrm{~s}^{-1}$ stronger jet (Fig. 5).

A striking feature helps distinguish the maritime from the inland atmospheric environments. Over the ocean, IOP1 and IOP4 showed a shallow westerly wind component, except for the relatively active ChocoJet period in IOP4 during 25-28 November (Fig. 5). In contrast, IOP2 and IOP3 showed deeper westerly flow, reaching up to $800 \mathrm{hPa}$, which was somehow affected by the orographic barrier located to the east that prevents easterlies at low levels.

Observed diurnal variability. At diurnal scales, moister and cooler westerlies at low levels (from ChocoJet) prevail during afternoon hours, in combination with warmer and drier easterlies at midlevels that cause highly unstable conditions inducing convection inland (Fig. 7). In general, this afternoon circulation is consistent with the diurnal cycle near the coast, as shown by inland observations (Fig. 8). At low levels, the variability of the winds was consistent with valley-mountain and land-sea contrasts. During IOP2, a shallow westerly late afternoon flow of 2-3 $\mathrm{m} \mathrm{s}^{-1}$ contrasts with the $1 \mathrm{~m} \mathrm{~s}^{-1}$ easterly nighttime flow, which is likely related to the drainage current from the sierra to the east. A similar diurnal pattern is observed during IOP3 but with a more accentuated and deeper late afternoon westerly flow. At midlevels, a noticeable easterly flow dominated all IOPs with more intense flow during IOP1 and IOP2 than during IOP3 and IOP4. IOP1 showed a weak low-level westerly component in the afternoon [1900 LST (0000 UTC)] and low-level easterly flow during morning hours. IOP2 and IOP 3 showed a weak low-level westerly wind component, which was enhanced during the afternoon (1900 LST; especially during IOP3) apparently because of a sea breeze in combination with a valley-mountain local circulation 
pattern. It is interesting that low-level afternoon flow was larger during IOP3 (wet season) than IOP2 (dry season), recalling that both inland campaigns were carried out along the western flank of the western range of the Andes. In contrast, López and Howell (1967) argued that katabatic winds are greater during the dry season over the eastern flank of the western range (southern location of the inland field campaigns). During IOP4, the westerly wind component was predominant throughout the day. Westerlies were stronger during the afternoon (1900 LST), however, and weaker during the morning hours [0700 LST (1200 UTC)]. Midlevel winds in IOP3 showed relatively large diurnal variability with weak westerlies at midnight [0100 LST (0600 UTC)] and easterlies during the early afternoon [1300 LST (1800 UTC)]. Reanalysis products show easterlies all day long (not shown).

Observational clues of the gravity waves. The diurnal variations of the zonal wind shown in Fig. 8 have been related to a mechanism that appears to be linked to the diurnal cycle of precipitation in the region (Mapes et al. 2003b). Over the Colombian western range of the Andes, late-afternoon showers developed, likely driven by sea-valley breezes (Jaramillo et al. 2017) combined with the rather weak but steadier ChocoJet.
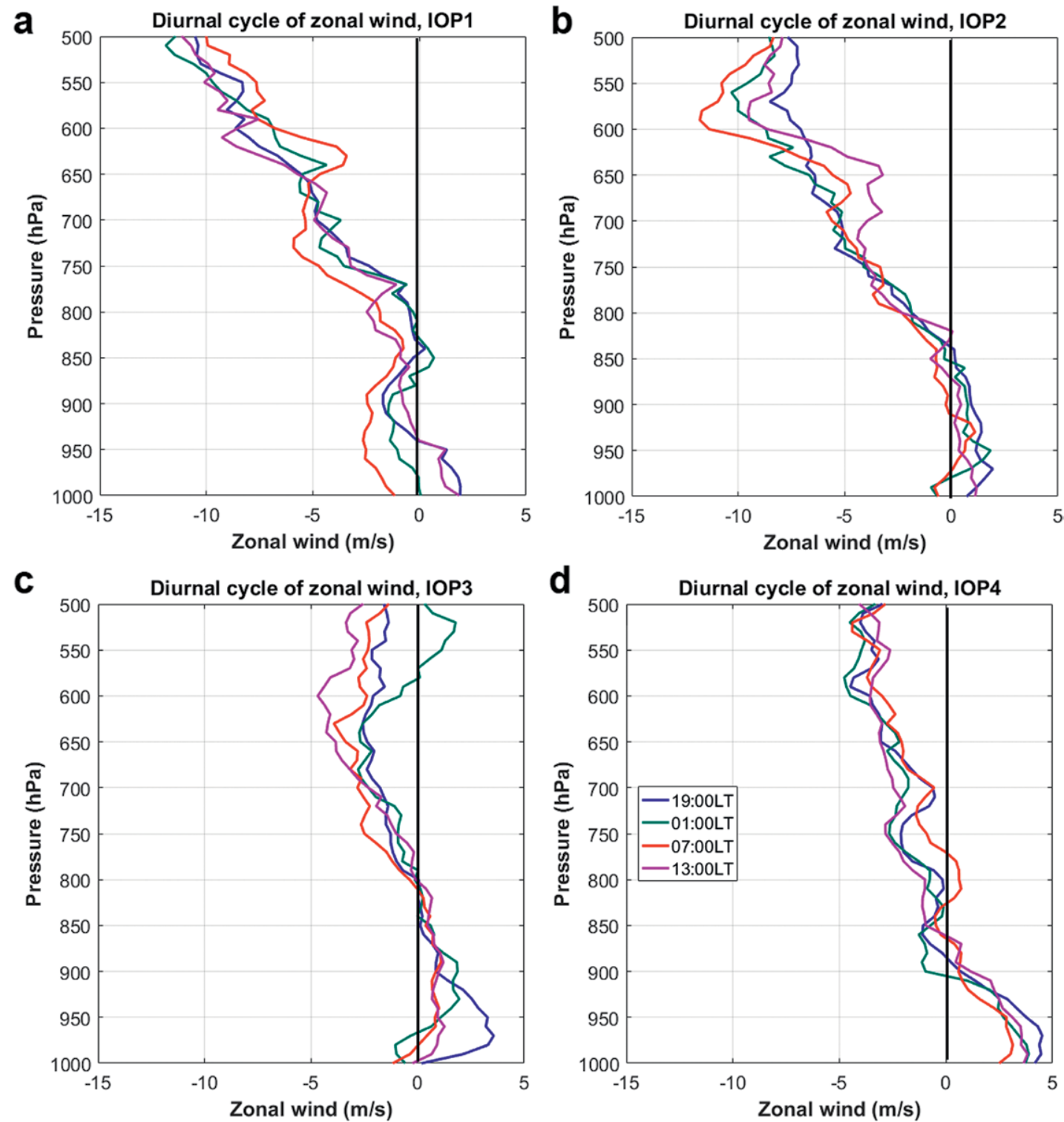

FIG. 8. Diurnal cycle of observed zonal wind averages ( $\mathrm{m} \mathrm{s}^{-1}$ ) during (a) IOPI (Jan 2016; on ocean), (b) IOP2 (Jun 2016; inland), (c) IOP3 (Oct 2016; inland), and (d) IOP4 (Nov 2016; on ocean). Local times relative to Colombia are UTC $-5 \mathrm{~h}$. 
In contrast, late night and morning convection over coastal waters has been related to midlevel gravity waves developed by the daytime mixed layer over the western Andes mountain range (Yang and Slingo 2001; Mapes et al. 2003b). The role of gravity waves triggering offshore convection has been studied in other regions with characteristics similar to those of western Colombia (Love et al. 2011; Li and Carbone 2015; Zhou and Wang 2006; Yokoi et al. 2017). For instance, Yokoi et al. (2017) used soundings to show that the lower troposphere offshore of Sumatra tends to cool down during late afternoon before the onset of precipitation.

Figure 9 shows the observed potential temperature profile after removing the mean diurnal cycle averaged during each IOP. Not surprisingly, inland campaigns (IOP2 and IOP3) showed relatively stronger warm daytime theta anomalies extending
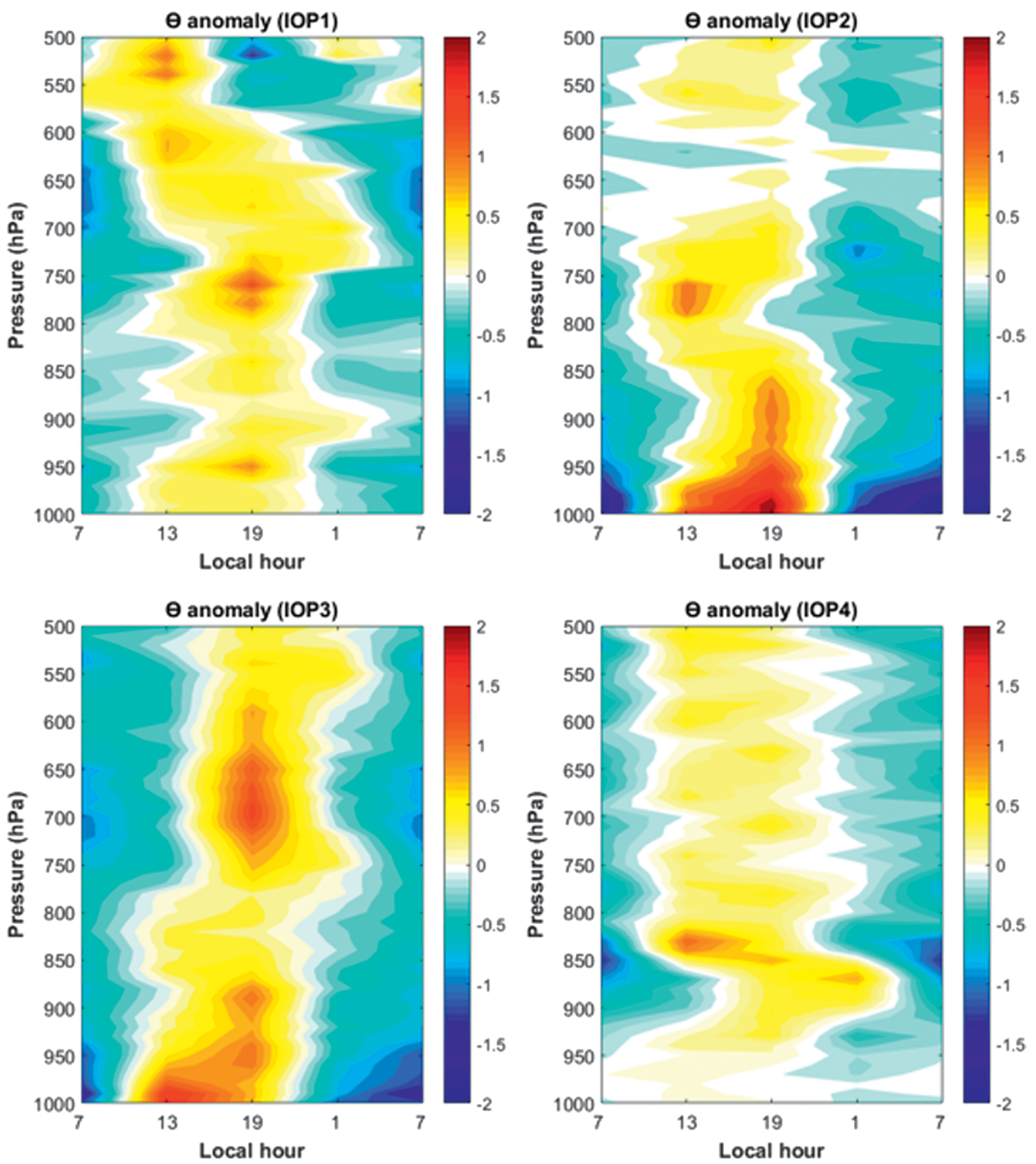

FIG. 9. Diurnal cycle of potential temperature $(\Theta)$ anomalies (K) during IOPI (Jan 20I6; on ocean), IOP2 (Jun 2016; inland), IOP3 (Oct 2016; inland), and IOP4 (Nov 2016; on ocean). Local times relative to Colombia are UTC - 5 h. 
from the surface to $850 \mathrm{hPa}$. Absolute surface maxima developed at 1900 LST for IOP2 and 1300 LST for IOP3 as determined by 6-hourly observations. We hypothesize that this surface asymmetry was likely due to differences in cloudiness and convection activity during the campaigns. Despite being developed over the ocean, the maritime campaigns showed a diurnal but weaker thermal disturbance, even at high levels, with IOP4 showing a weaker thermal disturbance than IOP1. Theta disturbances for IOP4 were composited using soundings located farther offshore than IOP1. Of note in Fig. 9 is the inland midlevel layer $(850-750 \mathrm{hPa})$ discontinuity in daytime heating, related to a flow direction change with height, suggesting the presence of two different air masses with a westerly (Fig. 8), wetter, and slower heating response bottom layer, contrasting an easterly, drier, and warmer theta midlevel layer right above. A striking feature in Fig. 9 is the lagged heating differences between land and maritime soundings, suggesting the existence of a midlevel westward thermal propagation, arguably because of the postulated gravity waves.

Potential temperature anomalies between 850 and $900 \mathrm{hPa}$ in IOP4 revealed cooling in the early morning likely related to the initiation of convective activity offshore (IR images show cloud occurrence at $0700 \mathrm{LST}$ ), as proposed by Mapes et al. (2003b). We hypothesize that the anomalous cooling is likely caused by vertical advection in the atmosphere favoring convection conditions, as is the case in Sumatra (Yokoi et al. 2017). They argue that both cooling and vertical ascent are caused by shallow gravity waves with a horizontal phase speed of $8-10 \mathrm{~m} \mathrm{~s}^{-1}$, and such hypothetical gravity waves are consistent with the timing of the late-afternoon cooling observed over the ocean. The processes are triggered by evaporative cooling from inland convective systems that generate gravity waves with ascending wave fronts in the lower troposphere and that propagate offshore horizontally (Hassim et al. 2016). Note that for Colombia's case, the cooling is lagged with respect to Sumatra, showing the cooling in the early morning hours (Fig. 9). Also, larger convective instability indices (CAPE, surface$6-\mathrm{km}$ vertical shear, and helicity) were observed during the late afternoon (1900 LST) in IOP1, IOP2, and IOP3 and during the early morning (0700 LST) in IOP4, when convection started on coastal waters and land, respectively (not shown). Unfortunately, our observations were not simultaneous and to investigate the role of the cooling at low levels in the formation of convection, model simulations are required. Future work will include the analysis of hourly simulations at different spatial scales during the IOPs that allow comparisons of simultaneous atmospheric profiles on ocean and land. Temperature, humidity, and wind anomalies will help us to investigate the association of the gravity waves with the convection generation. Likewise, observations provided from CHOCO-JEX will evaluate the model performance.

FINAL REMARKS AND SUMMARY. CHOCOJEX provided upper-air observations over the far eastern tropical Pacific during four intensive observational periods: two carried out over a research vessel following operational reconnaissance maritime transects and two inland (Quibdó, Colombia). Upper-air soundings were performed four times per day with an average of seven days per IOP. Data analysis and assimilation including these observations, in combination with simulation experiments, is currently in progress and is intended to improve our understanding of the mechanisms responsible for the genesis and diurnal timing of the convection organization in one of the rainiest regions on Earth. Preliminary results and remarks are as follows:

1) CHOCO-JEX provided atmospheric soundings during different seasonal and synoptic conditions. IOP1 was performed during a particularly strong El Niño event (2015/16).

2) Maritime observations during IOP4 provided the first observational evidence of the southwesterly low-level ChocoJet. The persistence and intensity of ChocoJet was modulated by Hurricane Otto that developed over the western Caribbean.

3) Land-atmosphere interactions (IOP2 and IOP3) revealed a deeper westerly flow and stronger diurnal cycle than observed over the ocean (IOP1 and IOP4).

4) Noticeable sea-land and valley-mountain local circulation patterns were observed as a response to the surface thermal contrast during IOP1 and IOP3.

5) Flow and thermal diurnal variations at $850 \mathrm{hPa}$ were observed with an intriguing delay (cooling at early morning hours) of maritime responses relative to inland mean diurnal anomalies, possibly supporting the role of the Andes convective and boundary layer processes in the far eastern Pacific convective environment. A question remains as to whether the observed cooling either occurs by advection, propagation of a gravity wave disturbance (Mapes et al. 2003b), or a combination of both processes. Further analysis may provide an answer to this question. 
Further examination of these CHOCO-JEX observations, including comparisons against reanalysis data, is necessary. Recall that IOPs were deployed during different seasons and that maritime soundings were averaged despite the constantly changing sounding locations. Another research paper using data assimilation procedures and Lagrangian trajectories is being prepared to further explore the significance of the outlined features, since they may help elucidate the gravity wave genesis hypothesis (Mapes et al. 2003b) and its role on convective organization postulated by simulation studies in the region. CHOCO-JEX will help us to evaluate and constrain mesoscale and high-resolution simulations and improve our understanding of the role of boundary layer and convective processes over the Andes, including the effects of latent heat released during organized convection systems in triggering westward-moving, midlevel thermal disturbances propagating from land to the ocean, as proposed by Mapes et al. (2003b). Other questions of interest include the following: What is the influence of heat fluxes and PBL on the observed rain patterns along the Colombian Pacific coast? What is the role of the Chocó-Darién rain forests in terms of water and energy budgets over the Colombian Pacific? What is the relation of moisture flow to the generation of MCSs and orographic rainfall in the Colombian Pacific region? How important is the ChocoJet in explaining the rainfall patterns across Colombia?

While improving our knowledge of the relevant circulation features in the region, CHOCO-JEX also addresses the communication and interaction gap between local academia/researchers and end-user institutions. The tools and equipment acquired by CHOCO-JEX, the established local and international collaborations, and the resulting datasets are building research capacity and potentially can further support a greater understanding of the region's hydrometeorology. Observations generated by these campaigns have been distributed to key operational and research centers in the region and will be distributed to any interested researchers and institutes.

ACKNOWLEDGMENTS. It is a pleasure to acknowledge the scientists, students, collaborators, and local volunteers from the Universidad Nacional de Colombia, Universidad Tecnológica del Chocó, DIMAR, FAC, and DRI who participated in the planning, execution, and data analysis for CHOCO-JEX. Special thanks are due to Brian E. Mapes for encouraging us to explore relevant ideas and to Leswis Cabeza, Carlos Forero, and Mauricio Jiménez for their collaboration during the field campaigns.
CHOCO-JEX was partially funded by the Colombian Administrative Department of Science, Technology and Innovation (COLCIENCIAS) and its Science, Technology, and Innovations in Geosciences program (No. 660 of 2014). DIMAR, FAC, DRI, and Universidad Nacional de 000000000 contributed with invaluable in-kind support during the whole CHOCO-JEX experiment. We thank the three anonymous reviewers and the editor, Ed Zipser, for providing comments that significantly improved this paper.

\section{REFERENCES}

Álvarez-Villa, O. D., J. I. Vélez, and G. Poveda, 2011: Improved long-term mean annual rainfall fields for Colombia. Int. J. Climatol., 31, 2194-2212, https:// doi.org/10.1002/joc.2232.

Amador, J., 2008: The intra-Americas sea low-level jet: Overview and future research. Ann. N. Y. Acad. Sci., 1146, 153-188, https://doi.org/10.1196 /annals.1446.012.

— E. J. Alfaro, O. G. Lizano, and V. O. Magaña, 2006: Atmospheric forcing of the eastern tropical Pacific: A review. Prog. Oceanogr., 69, 101-142, https://doi .org/10.1016/j.pocean.2006.03.007.

Arias, P. A., J. A. Martínez, and S. C. Vieira, 2015: Moisture sources to the 2010-2012 anomalous wet season in northern South America. Climate Dyn., 45, 2861-2884, https://doi.org/10.1007/s00382-015 $-2511-7$.

Arnett, A. B., and C. R. Steadman, 1970: Low-level wind flow over eastern Panama and northwestern Colombia. ESSA Tech. Memo. ERLTM-ARL 26, Air Resources Laboratory, Silver Spring, MD, 73 pp.

Bedoya-Soto, J. M., G. Poveda, K. Trenberth, and J. Vélez, 2018: Interannual hydro-climatic variability and the 2009-2011 extreme ENSO phases in Colombia: From Andean glaciers to Caribbean lowlands. Theor. Appl. Climatol., https://doi.org/10.1007 /s00704-018-2452-2.

Bookhagen, B., and M. R. Strecker, 2008: Orographic barriers, high-resolution TRMM rainfall, and relief variations along the eastern Andes. Geophys. Res. Lett., 35, L06403, https://doi.org/10.1029 /2007GL032011.

Cook, K. H., and E. K. Vizy, 2010: Hydrodynamics of the Caribbean low-level jet and its relationship to precipitation. J. Climate, 23, 1477-1494, https://doi .org/10.1175/2009JCLI3210.1.

CPPS, 2017: Boletín de Alerta Climático. No. 321, Comisión Permanente del Pacífico Sur (Permanent Commission of the South Pacific), 20 pp., www.dhn .mil.pe/Archivos/Oceanografia/BAC/06-2017.pdf. 
Douglas, M. W., J. Mejía, N. Ordinola, and J. Boustead, 2009: Synoptic variability of rainfall and cloudiness along the coasts of northern Peru and Ecuador during the 1997/98 El Niño event. Mon. Wea. Rev., 137, 116-136, https://doi.org/10.1175/2008MWR2191.1.

Durán-Quesada, A. M., M. Reboita, and L. Gimeno, 2012: Precipitation in tropical America and the associated sources of moisture: A short review. Hydrol. Sci. J., 57, 612-624, https://doi.org/10.1080 /02626667.2012.673723.

Eslava, J., 1993: Some particular climatic features of the Colombian Pacific region. Atmósfera, 17, 45-63.

— , 1994; Climatología del Pacífico Colombiano. Colección Eratóstenes, No. 1, Academia Colombiana de Ciencias Geofísicas, 79 pp.

Gimeno, L. F., and Coauthors, 2016: Major mechanisms of atmospheric moisture transport and their role in extreme precipitation events. Annu. Rev. Environ. Resour., 41, 117-141, https://doi.org/10.1146/annurev -environ-110615-085558.

GMH, 2013: ¡BASTA YA! Colombia: Memorias de Guerra y Dignidad. Informe General Grupo de Memoria Histórica, 431 pp, www.centrodememoria historica.gov.co/micrositios/informeGeneral /descargas.html.

González, C., L. E. Urrego, and J. I. Martínez, 2006: Late Quaternary vegetation and climate change in the Panama basin: Palynological evidence from marine cores ODP 677B and TR 163-38. Palaeogeogr. Palaeoclimatol. Palaeoecol., 234, 62-80, https://doi .org/10.1016/j.palaeo.2005.10.019.

Grados, C., A. Chaigneau, V. Echevin, and N. Dominguez, 2018: Upper ocean hydrology of the Northern Humboldt Current System at seasonal, interannual and interdecadal scales. Prog. Oceanogr., 165, 123 144, https://doi.org/10.1016/j.pocean.2018.05.005.

Hassim, M. E. E., T. P. Lane, and W. W. Grabowski, 2016: The diurnal cycle of rainfall over New Guinea in convection permitting WRF simulations. Atmos. Chem. Phys., 16, 161-175, https://doi.org/10.5194/acp-16 $-161-2016$.

IDEAM, 2016a: Boletín Climático Mensual. January, 27 pp., www.ideam.gov.co/web/tiempo-y-clima /climatologico-mensual.

_ , 2016b: Boletín Climático Mensual. June, 29 pp., www .ideam.gov.co/web/tiempo-y-clima/climatologico -mensual.

— , 2016c: Boletín Climático Mensual. October, 28 pp., www.ideam.gov.co/web/tiempo-y-clima /climatologico-mensual.

— , 2016d: Boletín Climático Mensual. November, 28 pp., www.ideam.gov.co/web/tiempo-y-clima /climatologico-mensual.
Janowiak, J. E., P.A. Arkin, and M. Morrissey, 1994: An examination of the diurnal cycle in oceanic tropical rainfall using satellite and in situ data. Mon. Wea. Rev., 122, 2296-2311, https://doi.org/10.1175/1520 -0493(1994)122<2296:AEOTDC>2.0.CO;2.

Jaramillo, L., G. Poveda, and J. F. Mejía, 2017: Mesoscale convective systems and other precipitation features over the tropical Americas and surrounding seas as seen by TRMM. Int. J. Climatol., 37 (S1), 380-397, https://doi.org/10.1002/joc.5009.

King, M. J., M. C. Wheeler, and T. P. Lane, 2017: Mechanisms linking global 5-day waves to tropical convection. J. Atmos. Sci., 74, 3679-3702, https://doi .org/10.1175/JAS-D-17-0101.1.

L'Heureux, M. L., and Coauthors, 2017: Observing and predicting the 2015/16 El Niño. Bull. Amer. Meteor. Soc., 98, 1363-1382, https://doi.org/10.1175/BAMS -D-16-0009.1.

Li, Y., and R. E. Carbone, 2015: Offshore propagation of coastal precipitation. J. Atmos. Sci., 72, 4553-4568, https://doi.org/10.1175/JAS-D-15-0104.1.

López, M. E., and W. E. Howell, 1967: Katabatic winds in the equatorial Andes. J. Atmos. Sci., 24, 29-35, https:// doi.org/10.1175/1520-0469(1967)024<0029:KWITEA $>2.0 . \mathrm{CO} ; 2$.

Love, B. S., A. J. Matthews, and G. M. S. Lister, 2011: The diurnal cycle of precipitation over the Maritime Continent in a high-resolution atmospheric model. Quart. J. Roy. Meteor. Soc., 137, 934-947, https://doi .org/10.1002/qj.809.

Mapes, B. E., T. T. Warner, and M. Xu, 2003a: Diurnal patterns of rainfall in northwestern South America. Part I: Observations and context. Mon. Wea. Rev., 131, 799-812, https://doi.org/10.1175/1520 -0493(2003)131<0799:DPORIN>2.0.CO;2.

,-- , and,$- 2003 \mathrm{~b}$ : Diurnal patterns of rainfall in northwestern South America. Part III: Diurnal gravity waves and nocturnal convection offshore. Mon. Wea. Rev., 131, 830-844, https://doi.org/10.1175 /1520-0493(2003)131<0830:DPORIN>2.0.CO;2.

Martínez, I., L. Keigwin, T. T. Barrows, Y. Yokoyama, and J. Southon, 2003: La Niña-like conditions in the eastern equatorial Pacific and a stronger Chocó jet in the northern Andes during the last glaciation. Paleoceanography, 18, 1033, https://doi .org/10.1029/2002PA000877.

, D. Rincon, Y. Yokoyama, and T. Barrows, 2006: Foraminifera and coccolithophorid assemblage changes in the Panama Basin during the last deglaciation: Response to sea-surface productivity induced by a transient climate change. Palaeogeogr. Palaeoclimatol. Palaeoecol., 234, 114-126, https://doi .org/10.1016/j.palaeo.2005.10.022. 
Meisner, B.N., and P.A. Arkin, 1987: Spatial and annual variations in the diurnal cycle of large-scale tropical convective cloudiness and precipitation. Mon. Wea. Rev., 115, 2009-2032, https://doi.org/10.1175/1520 -0493(1987)115<2009:SAAVIT>2.0.CO;2.

Mejía, J. F., and G. Poveda, 2005: Atmospheric environments of mesoscale convective systems over Colombia during 1998 according to the TRMM mission and the NCEP/NCAR reanalysis (in Spanish). Rev. Acad. Colomb. Cienc., 29, 495-514.

Mollier-Vogel, E., G. Leduc, T. Böschen, P. Martinez, and R. Schneider, 2013: Rainfall response to orbital and millennial forcing in northern Peru over the last 18 ka. Quat. Sci. Rev., 76, 29-38, https://doi .org/10.1016/j.quascirev.2013.06.021.

Montoya, G. J., J. Pelkowski, and J. A. Eslava, 2001: Sobre los alisios del noreste y la existencia de una corriente en el piedemonte oriental Andino. Rev. Acad. Colomb. Cienc., 25, 363-370.

Murphy, R. C., 1939: The littoral of Pacific Colombia and Ecuador. Geogr. Rev., 29, 1-33, https://doi .org/10.2307/210063.

Myers, N., R. A. Mittermeier, C. G. Mittermeier, G. A. da Fonseca, and J. Kent, 2000: Biodiversity hotspots for conservation priorities. Nature, 403, 853-858, https://doi.org/10.1038/35002501.

Pahnke, K., J. P. Sachs, L. Keigwin, A. Timmermann, and S.-P. Xie, 2007: Eastern tropical Pacific hydrologic changes during the past 27,000 years from $\mathrm{D} / \mathrm{H}$ ratios in alkenones. Paleoceanography, 22, PA4214, https://doi.org/10.1029/2007PA001468.

Poveda, G., 2001: Leaders need to realize that science can offer a route out of poverty. Nature, 409, 662-662, https://doi.org/10.1038/35055714.

— 2004: Science priorities ignore Colombia's water needs. Nature, 431, 125-125, https://doi .org/10.1038/431125a.

— logical processes in tropical South America and large-scale ocean-atmospheric phenomena. $J$. Climate, 10, 2690-2702, https://doi.org/10.1175/1520 -0442(1997)010<2690:FBHPIT>2.0.CO;2.

— and — 1999: The westerly low-level Chocó jet and two other atmospheric jets over Colombia: Climatology and variability during ENSO phases (in Spanish). Rev. Acad. Colomb. Cienc., 23, 517-528.

—, and — 2000: On the existence of Lloró (the rainiest locality on Earth): Enhanced oceanland-atmosphere interaction by a low-level jet. Geophys. Res. Lett., 27, 1675-1678, https://doi.org /10.1029/1999GL006091.

—, A. Jaramillo, M. M. Gil, N. Quiceno, and R. I. Mantilla, 2001: Seasonality in ENSO-related precipi- tation, river discharges, soil moisture, and vegetation index in Colombia. Water Resour. Res., 37, 2169-2178, https://doi.org/10.1029/2000WR900395.

— , P. R. Waylen, and R. Pulwarty, 2006: Modern climate variability in northern South America and southern Mesoamerica. Palaeogeogr. Palaeoclimatol. Palaeoecol., 234, 3-27, https://doi.org/10.1016/j .palaeo.2005.10.031.

—, D. M. Álvarez, and O. A. Rueda, 2011: Hydroclimatic variability over the Andes of Colombia associated with ENSO: A review of climatic processes and their impact on one of the Earth's most important biodiversity hotspots. Climate Dyn., 36, 2233-2249, https://doi.org/10.1007/s00382-010-0931-y.

_, L. Jaramillo, and L. F. Vallejo, 2014: Seasonal precipitation patterns along pathways of South American low-level jets and aerial rivers. Water Resour. Res., 50, 98-118, https://doi.org/10.1002/2013WR014087.

Prange, M., S. Steph, M. Schulz, and L. D. Keigwin, 2010: Inferring moisture transport across Central America: Can modern analogs of climate variability help reconcile paleosalinity records? Quat. Sci. Rev., 29, 1317-1321, https://doi.org/10.1016/j .quascirev.2010.02.029.

Romero-Centeno, R., J. Zavala-Hidalgo, and G. B. Raga, 2007: Midsummer gap winds and low-level circulation over the eastern tropical Pacific. J. Climate, 20, 3768-3784, https://doi.org/10.1175/JCLI4220.1.

Rueda, O. A., and G. Poveda, 2006: Spatial and temporal variability of the Chocó low level jet and its effect on the hydroclimatology of the Colombian Pacific region (in Spanish). Colomb. Meteor., 10, 132-145.

Sakamoto, M. S., T. Ambrizzi, and G. Poveda, 2011: Moisture sources and life cycle of convective systems over western Colombia. Adv. Meteor., 2011, 890759, https://doi.org/10.1155/2011/890759.

Schmidt, R. D., 1952: Die Niederschlagsverteilung im Andinen Kolumbien. Bonner Geogr. Abhandl, 9, 99-119. Schneider, T., T. Bischoff, and G. H. Haug, 2014: Migrations and dynamics of the intertropical convergence zone. Nature, 513, 45-53, https://doi.org/10.1038 /nature13636.

Sierra, J. P., P. A. Arias, and S. C. Vieira, 2015: Precipitation over northern South America and its seasonal variability as simulated by the CMIP5 models. Adv. Meteor., 2015, 634720, https://doi.org/10.1155/2015/634720.

Snow, J. W., 1976: The climate of northern South America. Climates of Central and South America, W. Schwerdtfeg, Ed., Elsevier, 295-403.

Sulca, J., K. Takahashi, J. C. Espinoza, M. Vuille, and W. Lavado-Casimiro, 2018: Impacts of different ENSO flavors and tropical Pacific convection variability (ITCZ, SPCZ) on austral summer rainfall in South 
America, with a focus on Peru. Int. J. Climatol., 38, 420-435, https://doi.org/10.1002/joc.5185.

Torrealba, E. R., and J. A. Amador, 2010: La corriente en chorro de bajo nivel sobre los Llanos Venezolanos de Sur América. Rev. Climatol., 10, 1-10.

Trojer, H., 1958: Meteorología y climatología de la vertiente del Pacífico Colombiano. Rev. Acad. Colomb. Cienc., 10, 199-219.

Vera, C., and Coauthors, 2006: The South American Low-Level Jet Experiment. Bull. Amer. Meteor. Soc., 87, 63-77, https://doi.org/10.1175/BAMS-87-1-63.

Vernekar, A. D., B. Kirtman, and M. Fennesy, 2003: Lowlevel jets and their effects on the South American summer climate as simulated by the NCEP Eta Model. J. Climate, 16, 297-311, https://doi.org/10.1175/1520 -0442(2003)016<0297:LLJATE>2.0.CO;2.

Wang, C., 2007: Variability of the Caribbean lowlevel jet and its relations to climate. Climate Dyn., 29, 411-422, https://doi.org/10.1007/s00382-007 -0243-z.

Warner, T. T., B. E. Mapes, and M. Xu, 2003: Diurnal patterns of rainfall in northwestern South America. Part II: Model simulations. Mon. Wea. Rev., 131, 813-829, https://doi.org/10.1175/1520-0493(2003)131<0813: DPORIN $>2.0 . \mathrm{CO} ; 2$.

Xie, S.-P., H. Xu, W. S. Kessler, and M. Nonaka, 2005: Air-sea interaction over the eastern Pacific warm pool: Gap winds, thermocline dome, and atmospheric convection. J. Climate, 18, 5-25, https://doi .org/10.1175/JCLI-3249.1.
Yang, G. Y., and J. Slingo, 2001: The diurnal cycle in the tropics. Mon. Wea. Rev., 129, 784-801, https:// doi.org/10.1175/1520-0493(2001)129<0784:TDCITT $>2.0 . \mathrm{CO} ; 2$.

Yokoi, S., S. Mori, M. Katsumata, B. Geng, K. Yasunaga, F. Syamsudin, and K. Yoneyama, 2017: Diurnal cycle of precipitation observed in the western coastal area of Sumatra Island: Offshore preconditioning by gravity waves. Mon. Wea. Rev., 145, 3745-3761, https:// doi.org/10.1175/MWR-D-16-0468.1.

Zhao, N., and L. D. Keigwin, 2018: An atmospheric chronology for the glacial-deglacial eastern equatorial Pacific. Nat. Commun., 9, 3077, https://doi .org/10.1038/s41467-018-05574-X.

Zhou, L., and Y. Wang, 2006: Tropical Rainfall Measuring Mission observation and regional model study of precipitation diurnal cycle in the New Guinean region. J. Geophys. Res., 111, D17104, https://doi .org/10.1029/2006JD007243.

Zuluaga, M. D., and G. Poveda, 2004: Diagnóstico de sistemas convectivos de mesoescala sobre Colombia y el océano Pacífico oriental durante 1998-2002 (Diagnostics of meso-scale convective systems over Colombia and the eastern Pacific Ocean during 19982002). Av. Recur. Hidrául., 11, 145-160.

— , and R. A. Houze Jr., 2015: Extreme convection of the near-equatorial Americas, Africa, and adjoining oceans as seen by TRMM. Mon. Wea. Rev., 143, 298-316, https://doi.org/10.1175/MWR-D-14 -00109.1 . 